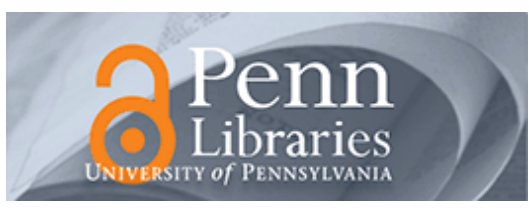

University of Pennsylvania
ScholarlyCommons

Departmental Papers (ASC)

Annenberg School for Communication

1978

\title{
Computer Systems: Prospects for a Public Information Network
}

Carolyn Marvin

University of Pennsylvania, cmarvin@asc.upenn.edu

Follow this and additional works at: https://repository.upenn.edu/asc_papers

Part of the Communication Commons

\section{Recommended Citation}

Marvin, C. (1978). Computer Systems: Prospects for a Public Information Network. Journal of Communication, 28 172-183.

https://doi.org/10.1111/j.1460-2466.1978.tb01670.x

This paper is posted at ScholarlyCommons. https://repository.upenn.edu/asc_papers/680

For more information, please contact repository@pobox.upenn.edu. 


\section{Computer Systems: Prospects for a Public Information Network}

\section{Disciplines}

Communication | Social and Behavioral Sciences 


\section{Computer Systems: Prospects for a Public Information Network by Carolyn Marvin}

\section{"Perhaps the very concept of equal access to information deserves examination. Is democracy literally the sum of informed choices by its citizens?"}

Visions of the future are perhaps never so welcome as at the end of a war when people are eager to turn their thoughts to new projects and more comfortable ways of life. World War II was no exception, and its prophets of the future built many of their dreams on the technical achievements of the war. In 1945 Arthur C. Clarke envisioned a worldwide system of orbiting extra-terrestrial relays beaming telephone and television signals over the earth's entire surface (9). As Clarke conceptualized new ways to transmit information, Vannevar Bush, whose Office of Scientific Research and Development had coordinated the wartime research, of 6,000 Allied scientists, was imagining new ways to store and retrieve it. Bush's efforts to meet the needs of far-flung researchers for large amounts of complex, technical knowledge interested him in the problem of making such information manageable and accessible.

The same year Clarke made his satellite prediction, Bush published his own prediction of the "memex," a desk furnished with a typewriter keyboard and a photographic unit for coding and transferring bibliographic and textual content into a large electronic storage unit (6). By typing out a unique index code, a user could scan' the information stored under that code on a television screen attached to the desk. The great value of the memex, as Bush conceived it, was its utility as a conceptual tool. Users would be able to build uniquely diverse and specialized schemes for classifying and consulting information by "associative trails," or meaningful connections between ideas, instead of by forcing them into ill-fitting traditional indexing categories built on alphabetic and numeric series. Each memex would also be able to transfer its own records to other memexes for storage and display so that a network of memex units could form an interactive system of information exchange.

Bush predicted the memex, which sounds to us like a modern video terminal linked to acomputer, at a time when the practical technology for it did not exist. The transistor amplifier, key to both satellites and computers, was still a few years away. Integrated circuits, silicon chips, and microprocessors-all the things that give modern computers their speed, capacity, and versatility-were unimaginable. Still, Bush felt the major obstacle to the system he had in mind was not technology, but the artificiality and unwieldiness of conventional indexing.

Bush's memex vision is no longer an extraordinary one. We are all acquainted with the ideal concept of a computer capability for delivering "total" information to everyone. In 1975 the National Commission of Library and Information Science offered its vision of a national electronic information network which would:

[p]rovide every individual in the United States with equal opportunity of access to that part of the total information resource which will satisfy the individual's location, social or physical condition or level of intellectual achievement $(23, \mathrm{p} . \mathrm{xi})$.

As Bush foresaw, the obstacles to such a system are not technological. Neither are they a matter of engineering costs. Sixteen thousand bytes of information which cost one million dollars to store in 1950 now can be stored for less than twenty dollars (8).

\section{What is expensive is software, the command and "indexing" system between a user, a computer, and a} data base.

So far, at least, more than a few standard software systems have been needed for the range of information problems which computers manage. The expense of designing and tailoring software systems to particular needs can only be borne by users with large capital resources, and only they are able to reap the benefits of information retrieval on any sizeable scale. These users are the biggest information processors in our society. They include Big Government, with its vast bureaucracies and military information requirements; Big Business, for inventory control, operations and transportation, and credit transactions of all kinds; and Big Science, especially in the field of medical research and records and in vast undertakings like the space program. Excluding data bases which are inaccessible to the public, as of 1975 more than 52 million electronic records were held in roughly 300 data bases worldwide, of which U.S. records account for about 89 percent (31, p. 20; see also 32). The largest single group of these data bases consists of scientific and technical information, or about 79 percent of total records held (see 10, pp. 2-15). 
Different data bases and searching systems frequently have various procedural protocols, and different ways of coding and locating information. Many of these are mutually incompatible; it is as though each were a different gauge of railroad track, incapable of being hooked together into a general transportation system. The resulting overlap in development, marketing, and maintenance costs keeps the price of on-line services high, and seems likely to restrict electronic information resources to economically elite users for some time to come.

Efforts are being made, however, to construct a national network of information to which the general public may have easy access. For the last decade, the major impetus for this project has come from the Library of Congress. The key to implementing such a network is, in the Library's view, its own format for recording, sorting, and processing basic bibliographic information on magnetic tape (3). Called MARC (an acronym for Machine-Readable Cataloging, officially MARC II, for revisions adopted in 1968), this format has so far been used primarily for library cataloging. Given MARC'S potential for information manipulation and retrieval, however, the Library of Congress hopes that MARC can be the basis for a national and even international system for many different kinds of information. Other groups argue that because MARC is descended from library cataloging, a classification system based on paper technology, it does not have the necessary capability or flexibility for a more inclusive system and, further, that MARC may even hinder the development of the national electronic information network.

\section{Any discussion about developing a public national information network must begin with existing suppliers} of electronic information and their customers.

At present these suppliers are commercial data base vendors and research libraries with interlibrary computer links for cataloging exchange. The customers, which could most easily be welded into a generally accessible information system are other research and public libraries, which do not regard the concept of a public information network with universal enthusiasm because of changes that network might portend for their traditional autonomy.

Commercial suppliers include both data base producers who build electronic data bases for the special requirements of single users or groups of users, and those who market electronic data bases as a sideline to their main business of producing printed abstracts and indexes. As computer-controlled printing has become a cheap alternative to traditional letterpress, one byproduct of computerized printing is a saleable electronic data base-a machine-readable collection of all items in the printed product. Information stored on magnetic tape or disc takes a fraction of the space allotted to volumes of equivalent printed matter and, unlike printed indexes, can be effortlessly updated. Indexing systems for electronic data bases derived from print formats often do not exploit the powerful logical capabilities of computer manipulation. But as long as profits from royalties for electronic searching are smaller than those from selling printed abstracts and indexes, little incentive exists to upgrade these systems or to make them compatible with other on-line services and data bases (16).

Data base brokers purchase or lease "files" from data base producers and make them available in package form to customers whose terminals are linked to the broker's computer. Major private on-line retrieval services in the United States include Lockheed Information System, whose DIALOG system begun in 1963 is certainly the oldest, Batelle Columbus Laboratories (BASIS), Mead Corporation (LEXIS), New York Times Information Services (Information Bank), and Informatics (RECON IV). Within each retrieval system, all data bases are converted into a common format, although different vocabularies and command procedures may be employed from file to file. Brokers competing for market shares are generally not concerned about inter-system compatibility. Large vendors mostly prefer that their systems be mutually exclusive since the resource-sharing advantages implied by compatible formats increase possibilities for competition from other companies (5). Large vendors thus duplicate among each other the fixed costs of computer software and data base maintenance and the major marginal costs of marketing and administration, and pass these costs on to their customers.

\section{In the last decade, libraries have also become actively involved in the electronic information field.}

This is a new role for the traditional guardians of print media which have long endured a stereotype of stodgy recalcitrance in the face of all technological advance after the printed book (21). At the head of the list is the Library of Congress, which has operated a free but purely local electronic information system for public use since May of 1977. The system consists of a dozen public terminals linked to computer files which contain cataloging data, information about pending legislation, and data on organizations that provide information services. The search system, SCORPIO (Subject-Content Oriented Retriever for Processing Information On-Line), taps all MARCformat files available to the public, and additional restricted files which are available to the Congressional Research 
Service. By late 1977, SCORPIO was said to be averaging 1,350 searches each day (7). The Library of Congress is also experimenting with on-line access by telephone dial-up for a selected group of libraries across the country (20). SCORPIO reference files will be available to these users, along with additional technical processing files which will permit connected libraries to catalog directly from Library of Congress MARC records.

Other research libraries have developed their own organizations and procedures for electronic information exchange. Non-profit bibliographic utilities, for example, compile and maintain on-line databases from which bibliographic processing and products are provided to networks of subscriber libraries linked to the computers of the bibliographic utility. One of the largest, the eleven-year-old Ohio College Library Center (OCLC), connects 2,100 terminals in some 1,340 research, public, federal, and other special libraries to a data base of some four million records (26). Whether the Library of Congress intends to become an on-line bibliographic utility competing with OCLC remains to be seen.

There are also library service centers organized by libraries cooperating at local, state, and regional levels. Service centers represent their members in contracting on-line services from private vendors and bibliographic utilities, often oversee physical implementation of these services, and may assist in library staff training. Sometimes they maintain regional files of location information or manage interlibrary loan and copying services. The oldest of these centers is the New England Information Network (NELINET), organized in 1965 and now serving 122 member libraries (24).

\section{Bibliographic utilities and library service centers are direct or indirect subscribers to the MARC catalog tapes of the Library of Congress.}

Since 1966 the Library of Congress has been distributing electronic cataloging records to a growing number of these subscribers; to date there are 63 (12). A single electronic catalog record can be produced on tape for a subscriber cost of $3 \%$ cents, while each catalog card costs from 5 cents to 45 cents to produce (14). Certain MARC tape subscribers like OCLC have become more efficient secondary distributors of catalog cards to individual libraries than the Library of Congress itself. These secondary distributors include abstracting and indexing firms, commercial jobbers, and others who purchase MARC tapes and produce printed cards from them more cheaply than the Library of Congress, with its less flexible labor contracts, can. Since 1969 these secondary distributors have been the cause of a precipitous and not unwelcome decline in orders for catalog cards printed by the Library (15).

The Library of Congress regards MARC as a powerful instrument for standardization because it is an information currency, a standard medium of information exchange applicable to bibliographic control. Standard formats and protocols make it possible to share large resource pools among independently developed systems, and facilitate the design and manufacture of both hardware and software. Special compatible MARC formats have been devised to catalog books, maps, films, music, serials, sound recordings, and even manuscripts in an alphanumeric set of 176 characters that can accommodate all Roman-alphabet languages (2).

MARC formats have also been adopted for information exchange outside the Library itself. MARC is used by the National Library of Medicine and the National Agricultural Library and by OCLC and its subscribers. It is the format for a special new networking project that permits the Research Library Group, a consortium of the libraries of Harvard, Yale, Columbia, and the New York Public Library, to share their resources through computer links, and by way of a hard wire connection between the New York Public Library and the Library of Congress, to consult the LC MARC data base $(1,19)$. MARC has been accepted as a standard by key organizations like the American Library Association and the American National Standards Institute. More than fifteen countries have implemented their own MARC projects (22), and UNIMARC is being developed internationally as a standard format into which each nation can translate bibliographic records for the purpose of exchange, and out of which it can translate records into its own unique national format. UNIMARC is proceeding under the auspices of a committee of both the International Federation of Library Associations, to which Eastern and Western European nations belong, and the International Standards Organization.

MARC is also the mother of formats, although its original developers would probably prefer to see MARC as the last of its line. The "empty container" format structure adopted by the American National Standards Institute under the title ANSI Z39.2-1971, and its subsequent revisions, were developed with MARC in mind, as have been newer and more flexible formats like UNISIST. In the computer standards community, however, MARC is regarded not as the mother of ANSI Z39, but as an "implementation" which fleshes out that skeletal structure with the content designators and data elements most appropriate to library cataloging. Other implementations, like the COSATI (Committee on Scientific and Technical Information) format used by the Defense Documentation Center and 
National Technical Information Service, use data elements and content designators which serve the needs of technical reports literature (17).

\section{It is important to view MARC in historical perspective, as only the latest stage in a long-term effort to develop a national public information network.}

This is not the first time that the growth of knowledge has made classification tools based on older communications technology unwieldy, or that the Library of Congress has taken a key role in organizing a national classification system. What is new is the magnitude of the post-war information explosion, and doubts as to whether the concerns of the Library of Congress are large enough to serve as the basis of a comprehensive public national information network.

The modern Library of Congress grew out of Thomas Jefferson's private library of 6,500 volumes which the nation purchased after British soldiers burned the first Library in 1814. The contents of the new Library were organized in 44 categories based on a system devised by Sir Francis Bacon in the sixteenth century to circumscribe all knowledge (15). These categories were adequate at a time when the quality and scope of personal collections frequently exceeded those of nations, so small was the volume of printed material generally. But 1814 was also the year of the invention of the steam-powered printing press, which heralded the unprecedented growth of the written word. By the 1870s the old alphabetical book catalogs in which large spaces were left at intervals for filling in additions to library collections were no longer efficient finding aids. Other solutions were needed.

The invention and adoption of the card catalog (in contemporary terms, a new kind of hardware) during the later part of the nineteenth century were important events in the history of information retrieval. Used together with new classification schemes like the Dewey decimal system (a new kind of software), the card catalog was flexible enough to accommodate rapid expansion in the quantity of printed material, and changes in the classification of ever broadening fields of knowledge. Card catalogs were also more democratic. They could be consulted by more than one person at once, and readers could work independently of librarians even in unfamiliar libraries.

The introduction of standard cataloging formats, however, made possible the first national library information network during the Andrew Carnegie period of American library expansion. Scores of inexpert new librarians needed bibliographic assistance which the Library of Congress could best provide through its expert staff and huge inventories of books. The utility of a central cataloging agency for the nation's libraries was articulated by many prominent librarians of the day, and their opinion was shared by the Librarian of Congress, Herbert Putnam. In 1901 he began printing multiple cards for every book catalogued by the Library, and organized a mail order system to send cards to every library that requested them. The success of this scheme required a standard way of recording information on each card, and a standard card size. In an age of standardization, it is hard for us to understand how many different sizes and systems of cards were in use - even at the Library of Congress itself (15). Putnam had to persuade hundreds of librarians, each loyally attached to his or her own idiosyncratic system, of the benefits of standardization. The situation was something like our own, in which efforts are being made to reduce the confusion of hundreds of software systems, machine languages, and machines.

The largest collection of bibliographic records assembled by the Library of Congress since it assumed the role of national bibliographic authority at the beginning of this century is the National Union Catalog, the most complete printed "data base" of library holdings in North America. Supplementary editions are added each four years. When the 1973-1977 cumulation is published, the entire catalog will comprise about 20 million records (12). Over the last twenty years, the growth in size of each successive four-year cumulation, from 28 volumes in the 1953-1957 edition, to 150 volumes for the 1973-1977 edition, offers one indication of the catalog's increasingly awkward size. ${ }^{1}$ It is startling to realize that a pioneer version of this catalog, which contained titles from all cards ever printed by the Library of Congress up to 1942, was 167 volumes, a size approached by the latest four-year edition alone (15).

Computerization may be necessary for national bibliographic records, but the general feasibility of computer tools developed especially for library use is not as clear. One reservation frequently voiced about MARC is that it is not constructed to handle "multiple levels" of data. Books and serials are the fundamental bibliographic units to which MARC is addressed. MARC is not equipped to identify and sort information about other kinds of units - separate journal articles, for example - without complex reprogramming or costly and redundant coding and searching procedures. Since journal articles constitute a voluminous and highly useful share of the information environment, this is a serious concern for users and producers of abstracting and indexing services.

Private vendors of electronic abstracts and indexes have made only limited use of MARC. Lockheed uses MARC in three of its 75 or so files (29); Systems Development Corporation has only one MARC file in its 46 data 
bases (4); Bibliographic Retrieval Services, serving a large library clientele, uses MARC in 6 of its 19 files (18). MARC, its detractors argue, has motorized the $3 \times 5$ card catalog and all its logical shortcomings without exploiting the powerful information dividing, combining, and handling capabilities of computers which are particularly useful for indexing purposes.

\section{Discussion of the merits of MARC or any other format also cannot be separated from the fact that state- of-the art advances turn yesterday's miracle solutions into today's clumsy obstacles.}

Increased new flexibilities in programming, particularly with the advent of high-speed disc storage, make MARC seem rigid and wasteful in comparison to newer implementations like UNISIST, a MARC-derived format being developed under the auspices of UNESCO and the Smithsonian Scientific Information Exchange for a world scientific information system (3). Such limitations are an important consideration in decisions to set up quasipermanent electronic systems. While human users of most large American libraries that date from the beginning of this century can and do tolerate without difficulty five or six different generations of catalog entry practices, a computer is a completely literal beast which cannot interpret variations and discrepancies. At the time of decision, however, necessity requires going ahead with the best available, rather than with the best possible, information system. Thus the Library of Congress's decade-old commitment of labor and resources to MARC II cannot be easily re-directed. The same applies to other libraries and institutions equipped to communicate in MARC format. Commercial vendors of scientific and technical information who have developed their own systems, earlier than MARC in some cases, also are understandably reluctant to adopt systems about which there is still debate even within the library community.

What is developing, therefore, is not a unified public electronic information network, but a competition among commercial systems, and disagreement in the public service sector about how best to proceed. Meanwhile, libraries that can afford to are becoming the clients of commercial vendors. To the extent that they have to recover costs for these new and expensive services, some of the library's traditional "free" public service functions are becoming fee-for-service offerings (13). If a large portion of the library community moves in the direction of commercial enterprise, small libraries which do not have the volume of use of electronic information which permits economies of scale may be squeezed out. If libraries of the future are to be more than distributors of commercial information services, they must enter into cooperative money-saving arrangements, or they must find capital to develop their own information capabilities. Federal grants to libraries have been steadily declining, and increased public funding is not likely. In spite of federal support and tax subsidies for private on-line retrieval systems during the early years of their development, moreover, search costs to consumers are still fairly high, and system compatibility low (16).

\section{If there is, in fact, little prospect of a unified public information network on the horizon, this is consistent with the existing American pattern.}

In the United States, channels of communication (post, telephone, telegraph, broadcasting, cable television, satellite) are directly regulated by government whereas information systems (wire services, newspapers, broadcast networks, book publishing, libraries, films, computer-based information systems) are not directly supervised. They are, of course, affected by government policies bearing on communications channels. If the exercise of government policy in the communications field has often left much to be desired, it is also true that without it, the most profitable services may be creamed off the top, and the interests, desires, and needs of ordinary people forgotten or discarded at the first sign of declining returns to shareholders. Until there is a "little black box" in every home, however, libraries do provide a system of tax-developed facilities for democratic access which also reflects a traditional commitment to information as a public good.

In the last analysis, the National Commission on Library and Information Science's hope that standard computer formats will bring the dream of "equal access" to information closer is a myth. There could never be equal access to all information, but perhaps only to certain kinds of information $(11,25)$. Even then, history suggests, just as often as old hierarchies of privileged knowledge break down, new ones arise. Perhaps the very concept of equal access of information deserves examination. Is democracy literally the sum of the informed choices of its citizens? Shall there be a "standard of information" expressed as a mathematical measure like the standard of living, imprecise in its indication of quality?

Someday an electronic National Union data base may be dialed up through regional networks from remote outlets equipped for a score of information functions including document delivery. Someday information may be 
ordered on-line through an interlibrary loan network much as airline seats are now reserved. Someday the housewife and scholar alike may subscribe to computer services which routinely select from among all the latest published articles those that match their personal and professional interest profiles, and deliver copies instantly to home or office. But is this the utopia we want?

Might the instantaneous character of automated information retrieval threaten certain types of knowledge that require more leisurely attention and reflection? Would that be an acceptable risk if every person had better access to information of a basic and utilitarian kind? Might the personal flexibility of "free browsing" through a book or a library be sacrificed to the marvelous but costly exactitude of computer logic in retrieval systems which value the measureable reward of the precise search for information over the less measureable, but no less rich, reward of the indirect search? Is it possible that standardization might erect walls of mutual unintelligibility higher and higher between major alphabet groups which cannot easily be cross-translated between computers? Or might the pressure of standardization sweep all before it and threaten the very existence of non-standard groups? Just as the extinction of Latin as the language of educated men occurred when new audiences began to demand cheaply printed materials in their own vernaculars, perhaps previously powerful languages will fall before the demands of a truly universal electronic information format-should one ever appear.

What we are actually looking forward to, meanwhile, is neither so utopian nor dystopian, but something more medieval in most libraries. Consider Widener Library, the largest library in the Harvard University system, where a single video terminal is locked, unseen by casual passersby, in its own separate room. If a reader persuades a reference librarian that he or she has a legitimate use to make of one of the files accessed by the Widener terminal, the librarian will unlock the room and key in the reader's inquiry. Users pay certain direct costs, and even for a simple search, ten to twenty dollars may be a minimum charge (on direct vs. mediated searching, see 27).

The librarian negotiates first with a user whose needs are perhaps only partly understood, and then with the system. This procedure is not very efficient, and it certainly is not cheap. The Widener computer search has its origins, it may be said, in the practice of chaining books to their locations in sixteenth-century monastic and cathedral libraries, and brings to mind a regulation issued by the library of Gotha in Germany late in the eighteenth century: "Anybody who wants to inspect a book has to apply to the librarian who will then show and, if need be, even allow him to read it" (28).

The reason for this parallel is clear. The intervention of the librarian in past centuries was necessary so long as books, like computers, were expensive relative to other forms of information. Not until three hundred years after the introduction of the printed book was any significant proportion of the population of Western Europe able to read it. It will likewise take time, though not centuries, for a substantial portion of the industrialized world to become computer-literate. The prospects for developing countries are less clear. Uneven network development and limited public access to computer-based information will certainly delay the diffusion of computer skills. But just as one of the revolutionary aspects of printing was its potential to make a copy of any book, and any idea, cheaply available to any person who wished to read it, and just as public libraries were organized to implement this possibility, we can expect that the use of computers by individuals for their own purposes and interests would constitute the most socially desirable and powerful use of computer technology.

\section{REFERENCES}

1."A report on the Activities of the Network Technical Architecture Group." Library of Congress Information Bulletin 36(17), April 29, 1977, pp. 290-291.

2. Avram, Henriette D. MARC: Its History and Implications. Washington, D.C.: Library of Congress, 1975.

3. Avram, Henriette D and Lenore S. Maruyama (Eds.) Toward a National Library and Information Service Network: The Library Bibliographic Component. Washington, D.C. : Library of Congress, 1977.

4. Black, Donald. Systems Development Corporation, Santa Monica, California. Telephone interview, June 1978. Figures as of May 1, 1978.

5. Bochmann, Gregor V. “Standards Issues in Data Communications.” Telecommunications Policy 1(5), December 1977, pp. $381-388$.

6. Bush, Vannevar. “As We May Think.” Atlantic Monthly 176(1), July 1945, pp. 101-108.

7. Caruso, Elaine. "Training and Retraining of Librarians and Users." Paper presented to Pittsburgh Conference on the On-Line Revolution in Libraries.” William Penn Hotel, Pittsburgh, Pa., November 16, 1977.

8. “Changes, Challenges, and Opportunities.” Geyer's Dealer Topics 142(7), July 1977. 
9. Clarke, Arthur C. Extra-Terrestrial Relays: Can Rocket Stations Give Worldwide Radio Coverage?" Wireless World 51(10), October 1945, pp. 305-308.

10. Cuadra, Carlos. “Commercially Funded On-line Retrieval Services-Past. Present, and Future.” Aslib Proceedings 30(1), January 1978.

11. Domestic Council on the Right of Privacy, Staff of. National Information Policy: Report to the President of the United States. Washington, D.C.: National Commission on Library and Information Science, 1976.

12. D’Ooge, Craig. Information Office, Library of Congress, Washington, D.C. Telephone interview, January 1978. Figures as of December 1, 1977.

13. Drake, Miriam. "Impact of On-line Systems on Library Functions." Pittsburgh Conference on the On-line Revolution in Libraries. William Penn Hotel, Pittsburgh, Pa., November 15, 1977.

14. Edlund, Paul. Executive Officer, Processing Department, Library of Congress, Washington. D.C. Interview, August 1977.

15. Edlund, Paul. “A Monster and a Miracle. The Cataloging Distribution Service of the Library of Congress, 1901-1976.” The Quarterly Journal of the Library of Congress 33(4), October 1976, pp. 383-421.

16. Gardner, Jeffrey J. and David M. Wax. “Online Bibliographic Services.” Library Journal 101(16), September 15, 1976, pp. 18271833.

17. Henderson, Madeline. "A Note on Federal Information Processing Standard." Bulletin of the American Society for Information Science 1(9), April 1975, pp. 25-26.

18. Kennedy, Keith. Bibliographic Retrieval Services, Scotia, New York. Telephone interview, June 1978. Figures as of June 1, 1978.

19. Knapp, John, Peter S. Graham, and S. Michael Malinconico. Establishment of Library Network On-Line Access to the Library of Congress MARC Data Base. Branford, Conn. : Research Libraries Group Office, January 14, 1976.

20. “Library Launches On-Line Distribution Service.” Library of Congress Information Bulletin 37(3), January 20, 1978, pp. 49, $52-53$.

21. Markuson, Barbara Evans. “Bibliographic Systems, 1945-1976.” Library Trends 25(1), July 1976, pp. 311-328.

22. Maruyama, Lenore S. Network Development Office, Library of Congress. Telephone interview, June 1978.

23. National Commission on Libraries and Information Science. Toward a National Program for Library and Information Services: Goals for Action. Washington D.C.: Government Printing Office, 1975.

24. New England Information Network, Wellesley, Mass. Telephone interview, June 1978. Figures as of May 1, 1978.

25. Privacy Protection Study Commission. Personal Privacy in an Information Society. Washington, D.C.: U.S. Government Printing Office, 1977.

26. Schieber, Phil. Editor, Ohio College Library Center, Columbus, Ohio. Telephone interview, June 1978. Figures as of May 1, 1978.

27. Rogers, Frank B. “Computerized Bibliographic Retrieval Services.” Library Trends 23( 1), July pp. 383-421. 1974, pp. 73-83.

28. Steinberg, S. H. Five Hundred Years of Printing, 3rd edition. New York: Penguin Books, 1974, p. 258.

29. Summit, Roger. Lockheed Information Systems, Palo Alto, Calif. Telephone interview, June 1978. Figures as of May 1, 1978.

30. UNISIST International Symposium on Information Systems and Services in Ongoing Research in Science. Proceedings. Budapest: Hungarian Central Technical Library and Documentation Centre, for UNESCO, 1976.

31. Williams, Martha and Ted Brandhorst. "Data about Data Bases.” Bulletin of the American Society for Information Science 3(2), December 1976.

32. Williams, Martha and Sandra H. Rouse (Eds.) Computer-Readable Bibliographic Data Bases. A Directory and Data Sourcebook. Washington, D.C.: American Society for Information Science, 1976. 
Note:

${ }^{1}$ Later editions are not strictly comparable to earlier ones because later editions do not contain records of as many kinds of bibliographic items. If they did, the growth of each successive edition would have been even greater

Carolyn Marvin is Lecturer at the Institute of Communications Research/Journalism Department of the University of Illinois. 